IZA DP No. 4857

If Seebohm Rowntree Had Studied Sweden:

How Poverty Changed in the City of Göteborg from 1925 to 2003

Björn Gustafsson

Birgitta Jansson

March 2010 


\title{
If Seebohm Rowntree Had Studied Sweden: How Poverty Changed in the City of Göteborg from 1925 to 2003
}

\author{
Björn Gustafsson \\ University of Gothenburg \\ and IZA
}

\author{
Birgitta Jansson \\ University of Gothenburg
}

\author{
Discussion Paper No. 4857 \\ March 2010
}

\author{
IZA \\ P.O. Box 7240 \\ 53072 Bonn \\ Germany \\ Phone: +49-228-3894-0 \\ Fax: +49-228-3894-180 \\ E-mail: iza@iza.org
}

Any opinions expressed here are those of the author(s) and not those of IZA. Research published in this series may include views on policy, but the institute itself takes no institutional policy positions.

The Institute for the Study of Labor (IZA) in Bonn is a local and virtual international research center and a place of communication between science, politics and business. IZA is an independent nonprofit organization supported by Deutsche Post Foundation. The center is associated with the University of Bonn and offers a stimulating research environment through its international network, workshops and conferences, data service, project support, research visits and doctoral program. IZA engages in (i) original and internationally competitive research in all fields of labor economics, (ii) development of policy concepts, and (iii) dissemination of research results and concepts to the interested public.

IZA Discussion Papers often represent preliminary work and are circulated to encourage discussion. Citation of such a paper should account for its provisional character. A revised version may be available directly from the author. 
IZA Discussion Paper No. 4857

March 2010

\section{ABSTRACT \\ If Seebohm Rowntree Had Studied Sweden: How Poverty Changed in the City of Göteborg from 1925 to 2003}

This paper investigates the development of poverty in Sweden using micro data derived from tax files for the city of Göteborg for the years 1925, 1936, 1947, 1958 as well as more recent (1983, 1994 and 2003) information. We define poverty as living in a household with a disposable income lower than a poverty line that represents a constant purchasing power all years, as well as poverty lines defined as 60 percent of contemporary median income. Clear reductions of poverty from 1925 to 1947 as well as from 1958 to 1983 are found. We argue that an important poverty reducing mechanism during both periods was narrowing earnings disparities. Further we claim that the poverty reduction from the end of the 1950 s to the first half of the 1980s was the outcome of improved transfer systems as well as the establishment of pronounced characteristics of present-day Sweden: the dual earner system.

JEL Classification: $\quad$ 132, N34, N94

Keywords: $\quad$ poverty, Sweden, Seebohm Rowntree, Gothenburg, earnings distribution, dual earner

Corresponding author:

Björn Gustafsson

Department of Social Work

University of Gothenburg

P.O. Box 720

SE 40530 Göteborg

Sweden

Email: Bjorn.Gustafsson@socwork.gu.se 


\section{Introduction}

Recent contemporary cross-country assessments indicate that Sweden has less poverty than most other rich countries ${ }^{1}$, and according to an assessment based not only on income, Sweden has the least. ${ }^{2}$ This raises the question: Was Sweden already a country of little poverty earlier in the 1900s? If not, when did poverty diminish? The first task for this paper is to contribute to the history of Swedish poverty. We describe financial poverty in the city of Göteborg 1925, 1936, 1947 and 1958 making it the first study for Sweden for this period. We report on the extent as well as the profile of poverty. ${ }^{3}$ As the data generating process changed thereafter we use two other data sources to illustrate the more recent poverty development (1983, 1994 and 2003), a development that for Sweden as a whole is covered in several other sources. ${ }^{4}$ However, our study does not only describe the poverty development, but also interprets the reasons for the changes. We do this by inspecting the poverty profile for the years under study, and by interpreting possible forces of change relying on others work on the evolution of key aspects in the Swedish society. ${ }^{5}$

Our research efforts can be put in perspective of the literature on poverty in rich countries. For many rich countries it is possible to assess the recent development of the extent and profile of poverty based on household income surveys. While such data collecting efforts started some decades ago, there is noticeably little knowledge on previous poverty situations. At present there is lively research on changes in income shares earned by the top income earners during the entire 1900s. ${ }^{6}$ In contrast, while it has now been more than one hundred years since Seebohm Rowntree published Poverty - A Study of Town Life (1901) ${ }^{7}$ based on fieldwork in York, and more than 50 years since he together with Lavers completed Poverty and the Welfare State (1951), ${ }^{8}$ there seems at present to be very little if any effort to assess the extent and profile of poverty during a significant part of the twentieth century. ${ }^{9}$

Why are there so few attempts to assess the development of poverty over a long period? Most likely, one important reason is conceptual. How should an analyst update a poverty line in a changing economy? There is no consensus in the research literature on contemporary poverty in rich countries, literature that is large and influenced by the fact that official or semi-official poverty assessments are regularly published by statistical authorities. For several decades there have been official statistics showing the extent and profile of poverty in the United

States. ${ }^{10}$ Another approach to official poverty assessment is found in the somewhat more 
recent efforts of the European Union. ${ }^{11}$ These two traditions differ on how to update the poverty line.

In the US approach, only changed consumer prices influence how the poverty line changes over time; in this sense it is an absolute approach, as the purchasing power of the poverty line is constant. In contrast, the main characteristic of the EU approach is to recalculate the poverty line based on the development of median equivalent income. This is a pure relativistic approach as the real purchasing power of the poverty line moves as the real value of the median changes. By applying both approaches to micro data we will here illustrate that the perception of the extent of poverty can be heavily affected by choice of approach. We will illustrate that the concept of pro-poor growth is useful in such comparisons. If growth is propoor during a certain period, then poverty assessed by a relative as well as an absolute manner of updating the poverty line decreases. ${ }^{12}$ Yet, if economic growth is pro-rich, poverty assessed by a relative poverty line is deemed to increase, while if assessed by an absolute poverty line it might be reported to be constant or even decrease. Besides having the purposes of adding to the history of Swedish poverty, this paper also aims to contribute to the ongoing debate on how to up-date the poverty line in rich countries by providing an empirical illustration. ${ }^{13}$

In addition to conceptual problems there are a host of measurement problems a researcher faces when trying to assess the development of the extent and profile of poverty over long periods. Well-based estimates require that key information is recorded and preserved at the household level. In order to make high quality comparisons over time, the data generating process should not have changed substantially during the period under study. Such considerations imply that an analyst aiming to assess the development of the extent and profile of poverty has to carefully consider issues such as definition of income and the income-receiving unit.

The rest of the paper is laid out as follows: In the next section we provide background for the empirical study by discussing some aspects of relevance for how poverty in Sweden developed over the preceding three-quarters of a century. The research strategy for the study is reported in Section 3. Results on how the extent of poverty has changed are found in Section 4, while Section 5 reports and discusses the changing poverty profile. Finally Section 6 concludes by summarising and discussing the findings. 


\section{Background}

As is already well-known, industrialisation came relatively late to Sweden, but well into the $20^{\text {th }}$ century economic growth moved faster than in many other European countries and unemployment fell. The world depression at the end of the 1920s/beginning of the 1930s and World War II affected Sweden less than many other countries. As opposed to previous years, unemployment remained at a low level for many years after World War II, and it was not until

the beginning of the 1990s that modern Sweden experienced high unemployment rates. ${ }^{14}$ Yet the recession at the beginning of the 1990s was deeper and lasted longer than recessions experienced by previous generations. While occupational wage differences were substantial in the mid 1920s, they tapered off for many years as lower earnings rapidly increased while changes at the top were small. Actually, from the mid-1970s to the first years of the 1980s, real wages at the top of the distribution decreased. This compression ended at the beginning of the 1980s when central bargaining was abolished, and real earnings started to increase most rapidly at the top of the distribution. ${ }^{15}$

On the whole, Sweden was not a leader in the creation of social insurance programmes. Not until 1948, the same year in which flat-rate child allowances were introduced, were pension benefits increased and began to reach a level adequate for full maintenance. The comprehensive sickness benefit system was launched in 1955, and after considerable political debate, the supplementary pension system began collecting funds in 1960. When these systems were in place, social insurance in Sweden had received much of what still characterises it. That is, the system is to a large extent universalistic in that all workers belong to one system administered by the social insurance office. ${ }^{16}$ The main exception is the unemployment benefit system. Previously coverage was far from high, but nowadays income losses are replaced for most days of unemployment. Many benefits are income related. The 1960s, 1970s, and to some extent the 1980s were periods of expanding transfer systems that channelled ever larger flows of funds to the households. ${ }^{17}$

Historically speaking, women in Sweden did not participate in paid labour. For example, the proportion of women in the labour force was not higher than 27 percent in 1930 and had changed only marginally (to 29 percent), in 1960. The economic significance of women working for household income was even lower than what these numbers suggest, as on average women worked fewer hours and earned considerably lower wages than men. 
However, much of this changed dramatically during the 1960s and 1970s. In 1980 women made up 45 percent of the labour force and ten years later the proportion had risen to 48 percent. The female/male earnings gap narrowed. As a consequence, married women's economic dependency on their husbands decreased rapidly. ${ }^{18}$ These spectacular changes were promoted by a changed tax policy in 1971, when the assessment unit for the progressive income tax moved from the couple to the individual. As a result, incentives for increased market work rose rapidly for the spouse with the lowest income, typically the wife. Increased female labour market participation was also promoted by expansion of heavily subsidised outof-home child care, making Sweden a prototype for the dual earner system. To this can be added the expanded replacement periods in the parental leave system from the 1980s on. As the gap in labour force participation rates between women and men decreased up to the beginning of the 90s it can be deemed to have been an important force in reducing poverty in Sweden for this period. ${ }^{19}$

Among several socio-demographic changes in Sweden during the last three-quarters of a century, some are of larger importance than others regarding the development of poverty. One is the tendency for young persons to start working life at an ever higher age. On the positive side, this means that younger birth cohorts have longer educations than formerly, a fact made possible by state-funded scholarships and loans. However, it also means that many persons aged 19 to 30 are in difficult positions financially when trying to gain a foothold in working life, and are typically not eligible for unemployment benefits. Further, they have left their parental homes and parents are not legally responsible for their maintenance, although it is not unusual with private transfers to offspring. ${ }^{20}$ Another socio-demographic change of importance for poverty development is the relatively large influx of migrants from distant low- and middle-income countries. Since the early 80s, many such workers have met large difficulties finding employment and as they have no work history (in Sweden), are not qualified for unemployment benefits. $^{21}$

\section{Research strategy}

The attractiveness of a local study on poverty is its manageability when resources are not plentiful. A disadvantage is that the location chosen might not be very typical. In addition, studying one single location means that interregional aspects cannot be covered. Based on 
convenience we chose to study the city of Göteborg, an industrial city on the Swedish west coast. $^{22}$ Table 1 report its population size (along with sample sizes) for the years studied.

For studying the period from the mid-1920s to the second part of the 1950s we use the Göteborg database which was created to study the change in income distribution for this period. $^{23}$ The sample was drawn from a manual register kept by the local tax authorities from 1917 to 1967 of all persons registered as residing in the city of Göteborg. From this register it was possible to obtain a random sample (applying no age limit) by drawing persons who were born on two specific days during the year including the members of the household. From this master sample four subsamples were drawn by selecting individuals who lived in Göteborg for the particular years studied.

Of primary importance was the choice of which years to investigate. For analysing changes over time it was thought essential to have a roughly equal number of years between years studied. Further, it was thought advisable to avoid years with too much macroeconomic turmoil as well as years of the two World Wars. Balancing the resources available between the size of the subsample and the number of subsamples, it was decided to collect data for four years. After considering the various points discussed above, the choice was made to investigate the years 1925, 1936, 1947 and 1958, which also means that years between each pair of years are not investigated.

/Table 1 about here/

In this data a household is defined as persons recorded to be living in the same apartment or single-family house with the same surname. This means that there can be people belonging to more than two generations in the household. The number of households in the subsample presented in Table 1 follows the growth of the population of Göteborg. The tax records are rich in income variables but reveal relatively few characteristics of the persons registered in the documents.

It was not possible to use an identical design for obtaining data of the same quality for Göteborg for more recent years. One analytic problem is that the Swedish public transfer system expanded during the 1960s and onwards; many income components received by lowincome households were not recorded in the tax records, as they were not subject to income 
tax. Further, the register used for sampling was discontinued in 1968 as the tax administration was computerised. We are therefore not in a position to report a fully consistent time series from 1925 to the beginning of the $21^{\text {st }}$ century, but have rather worked along two different lines. The first was to use a Göteborg subsample from the Swedish Income Panel (SWIP). This countrywide database consists of large longitudinal samples where samples were drawn from the Register of the Total Population (RTB) of Statistics Sweden (SCB), the modern follower of the register used for tax purposes. SWIP was constructed by taking a sample of 1 percent of Swedish-born persons from the RTB (for the year 1978), and a 10-percent sample of foreign-born persons, as well as additional samples (10 percent) from persons who immigrated in 1979,1980 , and each year up to $2003 .^{24}$

SWIP also includes information on spouses or partners who are parents to the same child, allowing us to define a household and receive the household's disposable income by adding disposable incomes of the partner. Table 1 reports that the subsamples range from 3526 in 1983 to 5333 in 2003. Variables in SWIP measure demographic circumstances collected from the RTB while most variables are derived by matching with the annual income registers of Statistics Sweden. From this follows that we have access to yearly information on disposable income. From 1983 onwards, the register has included information on amounts of received social assistance and housing allowance which led us to choose this year for the study. Note also that in several time series, the year 1983 marks a turning point in the development of income inequality and earnings inequality in Sweden. We also select two additional years to study with this data; 2003, the last year for which information was available when the study was made, and 1994 which lies approximately in the middle of the period defined by the other two years selected. In 1994 the Swedish economy was in a deep recession from which it had recovered (in many aspects) by 2003.

The advantage of the Göteborg subsample of SWIP is that it covers the location we are interested in - Göteborg. Its major disadvantage is its definition of household as it is narrow. A household can by definition not contain more than two adults (persons aged 18 and older). This means, for example, that a child living with his or her parents is treated as a separate household upon reaching age 18. Co-residing adults who are not married, and in addition do not have a common child, are also treated as separate income-receiving units. For these reasons, then, the poverty counts obtained from SWIP tend to provide poverty rates higher than poverty rates derived from the main source of contemporary estimates of poverty in 
Sweden, the Household Income Survey (HINK/HEK). ${ }^{25}$ This source is used for most crosscountry poverty comparisons. ${ }^{26}$ We therefore also use special tabulations from the Household Income Survey where the definition of household is very close to that of the Göteborg data for 1925, 1936, 1947 and 1958 as a supplement. The disadvantage of HINK/HEK for our purpose is that sample size does not allow households living in Göteborg to be broken down by characteristics when making poverty assessments. HINK/HEK has been conducted for many years, but the recent broad definition of the household has been only in regular use since 1995. Therefore we use HINK/HEK for the whole of Sweden for 1995 and 2003. In order to be comparable with certain previous estimates for the same data source, we apply a definition of income that includes imputed rents of owner-occupied housing, an income component not covered in the other datasets we use.

For the analysis we define equivalent income as the disposable income of the household corrected for its expenditure needs. The latter is expressed by a commonly used equivalence scale according to which the needs of the first adult are represented by the number 1 , needs for other adults by the number 0.7 , and the number 0.5 for each child (person under 18 years of age). ${ }^{27}$

\section{How the extent of poverty has changed}

/Table 2 about here/

In this section we report results on how the extent of poverty has changed. First, in Table 2 we report median household equivalent income as observed in our data and some comments can be made. The median in 2003 (in constant prices) is 4.8 times as high as in 1925. Poverty lines defined as 60 percent of the contemporary median are also reported in Table 2. We find that the purchasing power of such levels had increased by between 1.2 percent and year and 2.3 percent and year. For most periods these growth rates in median (or mean, also shown in the table) household income are slower than the growth in GDP per capita for Sweden. The difference reflects, among other things, changes in the relative size of the public sector, which expanded during most of the period under study.

/ Table 3 about here/ 
We apply the '60 percent of the median' poverty lines to our data for each year under study, update it for each year under study (both forward and backward) using the consumer price index, and report the results in Table 3. In the upper part of the table, the diagonal shows the proportion of people falling under the contemporary relative poverty line. This time series is also illustrated in Figure 1, where in addition we report poverty rates defined in the same manner for the entire country as reported by the Luxembourg Income Study (LIS) ${ }^{28}$, and HINK/HEK. We find that in 1925 the relative poverty rate for Göteborg was as high as 21.4 percent. This is comparable to the levels most recently observed for rich countries with comparatively high poverty rates. Examples of numbers (based on the Luxembourg Income Study) are 21 percent for the United Kingdom in 1999 and Spain in 2000, 23 percent for Ireland in 2000 and 24 percent observed for the United States in 2004.

/Figure 1 about here/

Figure 1 illustrates how the relative poverty rate for Göteborg fell in 1936 and then fell further in 1947 to the level of 15.8 percent (which is higher than the poverty rate observed in contemporary low-poverty countries according to LIS). However, the relative poverty rate was higher in 1958, but subsequently fell rapidly to 10.1 percent in $1983 .^{29}$ Since then relative poverty rates have increased. As seen in Figure 1, the poverty rate calculated from the SWIP subsample for the period 1983-2003 is higher than for the other series. One reason for this is differences in definition of the household. Note also the markedly larger difference between the two estimates for Sweden in 1995 though both are based on the same survey.

/Figure 2 and Figure 3 about here/

Reading Table 3 line by line makes it possible to report on poverty assessments based on a poverty line representing a constant purchasing power. ${ }^{30}$ Figure 2 supplements this by showing cumulative density functions for the first five years of measurement. We perform this exercise to learn if poverty comparisons can be made that is robust with respect to the level of the constant purchasing power poverty line. The horizontal axis shows income levels up to SEK 35000 a year, per person (in prices of 2003), and the vertical axis shows cumulated proportions of the population studied. In the figure it is rather clear that for any constant purchasing power poverty line, poverty decreased from 1925 to 1936 and decreased more dramatically from 1936 to 1947, a period that spans World War II. In contrast there is 
very little change from 1947 to 1958 . The reduction between 1958 and 1983 is rather dramatic at higher income levels which Figure 3 shows. This figure, which is constructed similarly to Figure 2 and shows cumulative density functions for the four years, also shows no changes or only small changes across the three last years of measurement. The only noticeable difference is a reduction from 1983 onwards limited to the relatively high income levels.

Clearly, basing poverty assessment for the earlier years under study on the most recent poverty lines carried backwards by the consumer price index (CPI), produces very high poverty rates. For example, basing the assessment on 60 percent of median income, as observed in SWIP 2003, leads to as much as 79 percent of the population of Göteborg in 1958 to fall under the line. The corresponding rate is as high as 89 percent for 1947 . Only 5 percent of the population of Göteborg in 1925 is not classified as poor if using the poverty standard of 2003. We believe that this illustrates the unsuitability of using poverty lines representing a fixed purchasing power for assessments over such a long period of substantial household income growth.

To sum up the findings in this section: We have reported evidence to support that the development of the extent of poverty in Sweden from 1925 to 2003 took place during four episodes (although the exact timing can be debated as we have not investigated each calendar year). From our first year under study (1925) to our measurement period close after World War II (1947), economic growth was pro-poor and poverty fell. This was a period of wage compression and decreased unemployment. This period was followed by one of no progress in poverty reduction. Between the years 1958 and 1983, a second episode of poverty reduction through pro-poor growth took place. During this period wage inequality decreased, public transfers as well as female labour force participation increased. Since 1983, economic growth in Sweden has been pro-rich and relative poverty rates are on the increase (though not necessarily those that are computed using a constant purchasing power). To more fully understand the reasons for the various changes, we will in the following section turn to how poverty has changed in various demographic groups focusing on age of the individual.

\section{The changed poverty profile}

/Figure 4 about here/ 
In Figure 4 we illustrate the proportion of people of a particular age under a poverty line set equal to 60 percent of contemporary median income for 1925, 1958 and $2003 .^{31}$ The curve is U-shaped in 1925, with the lowest rates for people aged 30 to 39, and by far the highest rates for those 65 and older. In 1958 poverty rates have fallen in most age groups and the profile has become flatter. The main exception to such widespread poverty reduction is among young adults. The comparably high poverty rates for young adults are also reported in 2003. The recorded relative poverty rate for children in 2003, 10 percent, is much lower than in 1925. Among adults, relative poverty rates decrease in 2003, reaching rather low values for people aged 50 to 64 . When turning to the elderly, the difference in poverty rates between 1925 and 2003 is dramatic. While in 1925 as many as 50 percent were classified as poor, in 2003 the corresponding proportion was down to 12 percent.

Looking more carefully into the data (not shown in the tables and figures presented here) for all years under investigation, some comments can be made on the pattern of change. Starting with relative child poverty rates, we observe decreases from 1925 for a long period followed by a visible increase from 1994 to 2003 (from 6.7 percent to 9.6 percent). Poverty rates for young adults are not shown to be higher than child poverty rates until 1958, a position they have maintained ever since. Poverty rates for people 65 and older have long been the highest of all age groups. They were (and still are) much higher for elderly persons living alone than for couples; the extreme is observed for 1936 when 80 percent of the elderly living alone were deemed poor. Yet, the relative poverty rate among the elderly gradually decreased and by 1958 had reached 40 percent, after which it plummeted to 4 percent in 1983, a development mainly driven by a drop in the poverty rates among elderly people living alone. Clearly the growth of the pension system is the main reason for the elimination of old age being synonymous with a high poverty risk. However, at the end of the period, relative poverty rates among the elderly are on the rise (from 7.4 percent in 1995 to 12.3 percent in 2003). This is due to larger fractions of the elderly living alone having incomes lower than an increasingly higher purchasing power of the poverty line.

/Table 4 about here/

In Table 4, which reports poverty rates for families with children, we find that single parents' poverty is rather high over a long period; several rates are higher than 50 percent. Like 
poverty rates for the elderly, single parent poverty rates fell dramatically between 1958 and 1983. This is likely due to several factors: increased labour force participation rates among single mothers facilitated by the growth of subsidised out-of-home child care, changes in the income tax system, the decreased gender wage gap, and the development of the transfer system. Here is where Sweden became famous for comparatively low single-parent poverty. ${ }^{32}$ Nevertheless, for some years now single-parent relative poverty has been on the rise. Relative poverty rates among foreign-born households have also increased in recent years as a consequence of increasing difficulty in becoming established in the labour market. According to tabulations from HINK/HEK, poverty rates are rather high for recently arrived immigrants, and decrease by year since immigration. For example, in 2003, 34 percent of adults residing less than10 years in Sweden were deemed poor, while for those with a longer residence, the figure was 13 percent. The poverty rate for native-born adults was 8 percent.

We end this section by reporting results from a multivariate analysis of poverty risks for the various years in order to better understand the changed pattern, and for this purpose we use the Göteborg and SWIP database. We are interested to find out how a poverty rate for a household with a given set of characteristics has changed over the years. For each year we have therefore estimated a logistic equation with poverty status as dependent variable. The independent variables are made up of a string of dummy variables indicating family type, another indicating socioeconomic group ${ }^{33}$ and a third indicating migration experience. For details, see Appendix 1. Based on the estimated model we predict the probability of being poor for a child and parents living in a family with at least two adults and the head having a low-skilled job. ${ }^{34}$ Further we assume no migration experience (internal for the first four years under study, international for the later three years). As an alternative we predict the probabilities of the head being a white-collar worker. The predictions are made using equations in which poverty is defined based on the contemporary median. As an alternative we also report predictions based on equations in which poverty is defined based on the real value of a poverty line defined from the 1958 median. ${ }^{35}$ Thus the two time series of predictions illustrate how poverty would be assessed using the approach of Eurostat and the United States, respectively.

/Table 5 about here/ 
Table 5 shows as expected that it makes a difference if the heads of households are unskilled workers or white-collar workers, as the latter are less likely to be poor. In 1925 as many as 29 percent of the children of blue collar workers were under the contemporary poverty line compared with only 5 percent among children of white collar workers, a gap of 24 percent. This gap had narrowed to 16 percent units in 1936, 12 percent in 1947, 11 percent units in 1958, and reached bottom at 2 percent in 1994 when as few as 5 percent of children in households headed by a native with limited education were predicted to be poor. However, in 2003 the gap had widened to 10 percent as the predicted probability had increased for the household with a low-educated head. ${ }^{36}$

It is interesting to see that the development of poverty among the unskilled appears rather different when basing the assessments on the 1958 poverty line updated forward and backward by the consumer price index only. In this case, many unskilled workers were likely to be poor at the beginning of the period and the gap towards white collar workers is even larger for the period before 1958. This illustrates how pro-poor growth pushed many families with children over the poverty line. On the other hand there is no sign of increased risk of being poor among families headed by a low-educated parent. This illustrates that since the first half of the 1980s, although growth has not been pro-poor, there has hardly been negative income growth among those at the bottom of the income distribution.

In Table 5C and D we have predicted the probability of being poor for a child in a two-adult immigrant family headed by a white-collar worker. We show results for newly arrived immigrants (5C), that are as expected the highest, and for immigrants who have resided in Sweden more than ten years (5D). The table shows that poverty assessed by a relative poverty line increased rather rapidly among immigrant children from 1994 to 2003. In contrast, when using the poverty line based on 60 percent of median income in 1958 updated with the consumer price index, rates remained low. Again we have an example of how perceptions of present poverty can differ fundamentally due to how the poverty line is updated.

\section{Conclusions}

In this paper we have aimed to contribute to the history of poverty in Sweden by studying the city of Göteborg, Sweden for the years 1925, 1936, 1947 and 1958 based on micro data. With 
the purpose of understanding the development over three-quarters of a century we have also provided poverty estimates for the same city for 1983, 1994 and 2003 and for the whole of Sweden for 1995 and 2003. Following the present practice of Eurostat when assessing poverty in the member states of the EU, we have worked with a poverty line set to 60 percent of the contemporary median. We have also updated the various poverty lines to represent a constant purchasing power backward and forward in time using the consumer price index. We have assessed the development of poverty, the changed profile of poverty and suggested interpretations for the changes. Studies of financial poverty over such a long period in a growing economy are rare, and different approaches on how to update a poverty line are today used in the United States and in the European Union.

The point of departure for this study was that contemporary Sweden is a country of comparably little poverty. In our study we found that in 1925, Göteborg was a city with a high extent of poverty. Thereafter poverty decreased until 1947, income growth was pro-poor during this period. We argue, but have not provided evidence from statistical analysis, that this development was driven by compressed earnings differences and decreases in unemployment. Such a development came to a halt and there was no progress in poverty reduction between 1947 and 1958, when relative poverty rates actually increased.

A second period of poverty reduction occurred between 1958 and 1983, a reduction that was rather rapid. Based on others writing we argue here that this period of pro-poor growth was the outcome of several forces: a new period of wage compression, the development of the transfer systems as well as increased female labour force participation which actually continued during all of the 80s. This process was promoted by changes in the income tax system and a rapid increase in heavily subsidized out-of-home child care. It was during this period Sweden earned its reputation as a low-poverty country.

However, as is already well known, since 1983 Sweden has not been characterised by further relative poverty reduction. Relative poverty is on the rise and economic growth has not been pro-poor. Factors responsible for the more recent development deserve more attention, but we can list some (that might be interrelated): A higher age of supporting oneself from work for young cohorts, a changed macroeconomic climate with a higher unemployment rate, increased wage inequality as well as the rise of immigrant poverty. 
We have further found that there have been large changes in the poverty profile during the period studied. In 1925 the elderly faced poverty rates that were dramatically higher than for other age groups. However, between 1958 and 1983, relative poverty rates for the elderly fell rapidly, and the same was true for poverty rates among single-parent families. In contrast, the most recent development is that relative poverty rates for single-parent households and for the elderly are on the rise. We have also found that since 1958, early adulthood stands out as a period of above average poverty risk in Sweden. Young adults in Sweden leave their parental homes much earlier than in for example southern Europe while often facing difficulty establishing themselves in the labour market.

The change for Swedish poverty for long being a problem disproportional affecting persons of old age to nowadays being a problem disproportionally affecting young adults, has likely meant that experiences of poverty has changed from being predominantly persistent to being temporary. In this sense can one assume that the contemporary poverty problem is less difficult to bear than the poverty that stroke the Swedish population some generations ago. However, the implication of the changed poverty profile has made it more difficult to formulate efficient policy measures to combat poverty. Historically increased pensions were the main strategy for reducing poverty at high age. Such a strategy is not feasible for combating the contemporary above-average poverty rates among young adults.

Finally, by applying different approaches in updating the poverty line we hope to contribute to the ongoing debate on how to update a poverty line. We have illustrated the limitations in updating a poverty line defined for one year to much earlier or much later years. For example, judging by income standards from 2003, as little as five percent of the population of Göteborg in 1925 would have been considered non-poor. Basing a poverty assessment on standards from 1925 would result in only two percent of the population in Göteborg in 1983 being considered poor. Further, the recent development in Sweden appears rather different if basing the poverty assessment on a poverty line representing a fixed purchasing power defined as 60percent of median income in 1958, or as 60-percent of contemporary median income. For example the deteriorating relative situation of many immigrants is captured only by the latter alternative.

That the poverty line for a society experiencing economic growth has to allow for increasing living standards in one way or another is far from new. Actually, Seebohm Rowntree used a 
poverty line that was higher than his original in his second study of York, by updating it to reflect how living expenditures had changed. ${ }^{37}$ Yet when poverty is officially assessed in the United States, a yardstick representing constant purchasing power is still used, decade after decade. 
Tables and figures to If Seebohm Rowntree had Studied Sweden - How Poverty Changed in the City of Göteborg from 1925 to 2003

Table 1. Population in Göteborg and samples 1925 - 2003.

\begin{tabular}{|l|c|c|c|c|l|l|}
\hline Year & $\begin{array}{l}\text { Population in } \\
\text { the city of } \\
\text { Göteborg / } \\
\text { Sweden }\end{array}$ & $\begin{array}{l}\text { Number of } \\
\text { households } \\
\text { in sample }\end{array}$ & $\begin{array}{l}\text { Sample } \\
\text { persons }\end{array}$ & $\begin{array}{l}\text { Average } \\
\text { household } \\
\text { size }\end{array}$ & $\begin{array}{l}\text { Share } \\
\text { of } \\
\text { foreign } \\
\text { born }\end{array}$ & Data source \\
\hline 1925 & 231007 & 1641 & 6850 & 4,17 & & $\begin{array}{l}\text { Göteborg } \\
\text { data }\end{array}$ \\
\hline 1936 & 262676 & 2197 & 7743 & 3,52 & & $\begin{array}{l}\text { Göteborg } \\
\text { data }\end{array}$ \\
\hline 1947 & 333272 & 2614 & 7929 & 3,03 & & $\begin{array}{l}\text { Göteborg } \\
\text { data }\end{array}$ \\
\hline 1958 & 397205 & 3363 & 9940 & 2,95 & $\begin{array}{l}\text { Göteborg } \\
\text { data }\end{array}$ \\
\hline 1983 & 424186 & 3526 & 6953 & 1,97 & 14,3 & SWIP \\
\hline 1994 & 444244 & 4509 & 9741 & 2,16 & 16,7 & SWIP \\
\hline 2003 & 478054 & 5333 & 11827 & 2,21 & 17,4 & SWIP \\
\hline & 8397570 & 16247 & 37545 & 2.31 & 10.3 & HEK \\
\hline 1995 & 8663861 & 17082 & 38401 & 2,25 & 10.8 & HEK \\
\hline 2003 & 8 & \multicolumn{7}{|c|}{ Entire Sweden } & & & \\
\hline
\end{tabular}

Source: Statistisk årsbok Göteborg, Authors’ calculations from Göteborg Data, SWIP and HINK/HEK 


\begin{tabular}{|c|c|c|c|c|c|}
\hline Year & $\begin{array}{l}\text { Median income } \\
\text { in fixed price } \\
\text { (2003) }\end{array}$ & $\begin{array}{l}\text { Poverty line - } \\
60 \text { percent of } \\
\text { median income } \\
\text { in fixed price } \\
\text { (2003) }\end{array}$ & $\begin{array}{l}\text { Household } \\
\text { annual } \\
\text { income } \\
\text { growth } \\
\text { (average) } \\
\text { percent }\end{array}$ & $\begin{array}{l}\text { Median } \\
\text { annual } \\
\text { growth } \\
\text { percent }\end{array}$ & $\begin{array}{l}\text { Swedish } \\
\text { GDP/capita } \\
\text { growth } \\
\text { percent }\end{array}$ \\
\hline 1925 & 28563 & 17138 & & & \\
\hline 1936 & 38188 & 22913 & 1,34 & 2,29 & 2,74 \\
\hline 1947 & 50271 & 30162 & 1,73 & 2,19 & 3,59 \\
\hline 1958 & 58085 & 34851 & 0,77 & 1,22 & 2,92 \\
\hline 1983 & 101042 & 60625 & 1,68 & 1,70 & 2,46 \\
\hline 1994 & 117229 & 70338 & 1,77 & 1,26 & 1,13 \\
\hline 2003 & 137175 & 82305 & 2,14 & 1,62 & 2,95 \\
\hline \multicolumn{6}{|c|}{ Information based on HINK/HEK for households living in the Gothenburg region } \\
\hline 1995 & 134672 & 80803 & & & \\
\hline 2003 & 168452 & 101071 & & & \\
\hline
\end{tabular}

Source: Authors' calculations from Göteborg Data, SWIP and HINK/HEK. Disposable income in the tabulations from HINK/HEK includes imputed rents from owner occupied housing, a component not covered in the other datasets used in this study.

\begin{tabular}{|c|c|c|c|c|c|c|c|}
\hline \multicolumn{8}{|c|}{$\begin{array}{l}\text { Table } 3 \text { Poverty according to different poverty lines. } \\
\text { Poverty line }=60 \text { percent equal or below median disposable income. }\end{array}$} \\
\hline Year & 1925 & 1936 & 1947 & 1958 & 1983 & 1994 & 2003 \\
\hline $\begin{array}{l}\text { Poverty line } \\
1925\end{array}$ & 21,4 & 12,4 & 7,3 & 9,5 & 2,4 & 3,3 & 3,7 \\
\hline $\begin{array}{l}\text { Poverty line } \\
1936\end{array}$ & 35,1 & 18,8 & 10,3 & 11,2 & 3,1 & 4,1 & 4,4 \\
\hline $\begin{array}{l}\text { Poverty line } \\
1947\end{array}$ & 53,1 & 31,9 & 15,8 & 14,8 & 3,7 & 4,8 & 5,0 \\
\hline $\begin{array}{l}\text { Poverty line } \\
1958\end{array}$ & 63,2 & 42,1 & 21,5 & 19,0 & 4,4 & 5,2 & 5,6 \\
\hline $\begin{array}{l}\text { Poverty line } \\
1983\end{array}$ & 90,0 & 82,9 & 66,5 & 53,7 & 10,1 & 9,6 & 9,4 \\
\hline $\begin{array}{l}\text { Poverty line } \\
1994\end{array}$ & 91,8 & 88,6 & 79,1 & 67,0 & 15,5 & 12,5 & 12,1 \\
\hline $\begin{array}{l}\text { Poverty line } \\
2003\end{array}$ & 94,7 & 92,7 & 89,2 & 79,1 & 27,6 & 18,6 & 16,5 \\
\hline \multicolumn{6}{|c|}{ Poverty in Sweden according to HINK/HEK } & 1995 & 2003 \\
\hline $\begin{array}{l}\text { Poverty line } \\
1995\end{array}$ & $\mathrm{x}$ & $\mathrm{x}$ & $\mathrm{x}$ & $\mathrm{x}$ & $\mathrm{x}$ & 6.5 & $\mathrm{x}$ \\
\hline $\begin{array}{l}\text { Poverty line } \\
2003\end{array}$ & $\mathrm{x}$ & $\mathrm{x}$ & $\mathrm{x}$ & $\mathrm{x}$ & $\mathrm{x}$ & $\mathrm{x}$ & 9.1 \\
\hline
\end{tabular}




\begin{tabular}{|c|c|c|c|c|}
\hline \multirow[t]{2}{*}{ Year } & \multicolumn{2}{|c|}{ One adult with one child or more } & \multicolumn{2}{|c|}{ Two adults with one child or more } \\
\hline & $\begin{array}{l}\text { Total number of } \\
\text { households } \\
\text { in the survey }\end{array}$ & $\begin{array}{l}\text { Total } \\
\text { percent } \\
\text { poor }\end{array}$ & $\begin{array}{l}\text { Total number } \\
\text { of households } \\
\text { in survey }\end{array}$ & $\begin{array}{l}\text { Total } \\
\text { percent } \\
\text { poor }\end{array}$ \\
\hline 1925 & 47 & 48,9 & 920 & 19,1 \\
\hline 1936 & 47 & 63,8 & 1074 & 16,0 \\
\hline 1947 & 76 & 55,3 & 1154 & 13,3 \\
\hline 1958 & 112 & 63,4 & 1596 & 14,7 \\
\hline 1983 & 185 & 15,9 & 815 & 7,7 \\
\hline 1994 & 416 & 22,2 & 1221 & 7,9 \\
\hline 2003 & 555 & 37,5 & 1581 & 13,9 \\
\hline \multicolumn{5}{|c|}{ Entire Sweden } \\
\hline & $\begin{array}{l}\text { Total number of } \\
\text { persons in the } \\
\text { survey }\end{array}$ & $\begin{array}{l}\text { Total } \\
\text { percent } \\
\text { poor }\end{array}$ & $\begin{array}{l}\text { Total number of } \\
\text { persons in the } \\
\text { survey }\end{array}$ & $\begin{array}{c}\text { Total } \\
\text { percent } \\
\text { poor }\end{array}$ \\
\hline 1995 & 631 & 7,8 & 10323 & 4.8 \\
\hline 2003 & 915 & 14,1 & 10086 & 6.6 \\
\hline
\end{tabular}

Source: Authors' calculations from Göteborg Data, SWIP and tables from HINK/HEK 
Table 5. Predicted probabilities for a child being poor $1925-2003$.

5.A Risks of being poor for a child in a family, natives, head of household unskilled worker 1925 to 2003

\begin{tabular}{|l|c|c|}
\hline Year & Poverty line & Poverty line 1958 \\
\hline 1925 & 29 & 86 \\
\hline 1936 & 20 & 56 \\
\hline 1947 & 19 & 28 \\
\hline 1958 & 19 & 19 \\
\hline 1994 & 5 & 3 \\
\hline 2003 & 13 & 2 \\
\hline
\end{tabular}

5.B. Risks of being poor for a child in a family, natives, head of household white collar 1925 to 2003

\begin{tabular}{|l|c|c|}
\hline Year & Poverty line & Poverty line 1958 \\
\hline 1925 & 5 & 15 \\
\hline 1936 & 4 & 14 \\
\hline 1947 & 7 & 7 \\
\hline 1958 & 8 & 8 \\
\hline 1994 & 3 & 1 \\
\hline 2003 & 3 & $<0.5$ \\
\hline
\end{tabular}

5.C. Risks of being poor for a child in an immigrant family, been in Sweden $0-4$ years,

head of household white collar 1994 and 2003

\begin{tabular}{|l|c|c|}
\hline Year & Poverty line & Poverty line 1958 \\
\hline 1994 & 24 & 3,5 \\
\hline 2003 & 60 & 4 \\
\hline
\end{tabular}

5.D. Risks of being poor for a child in an immigrant family, been in Sweden more than 10 years head of household white collar 1994 and 2003

\begin{tabular}{|l|c|c|}
\hline Year & Poverty line & Poverty line 1958 \\
\hline 1994 & 15 & 4 \\
\hline 2003 & 52 & 3 \\
\hline
\end{tabular}

Source: Predictions based on the multivariate analysis of poverty risks presented in Appendix 1 
Figure 1. Relative poverty rates in Sweden and Göteborg $1925-2003$

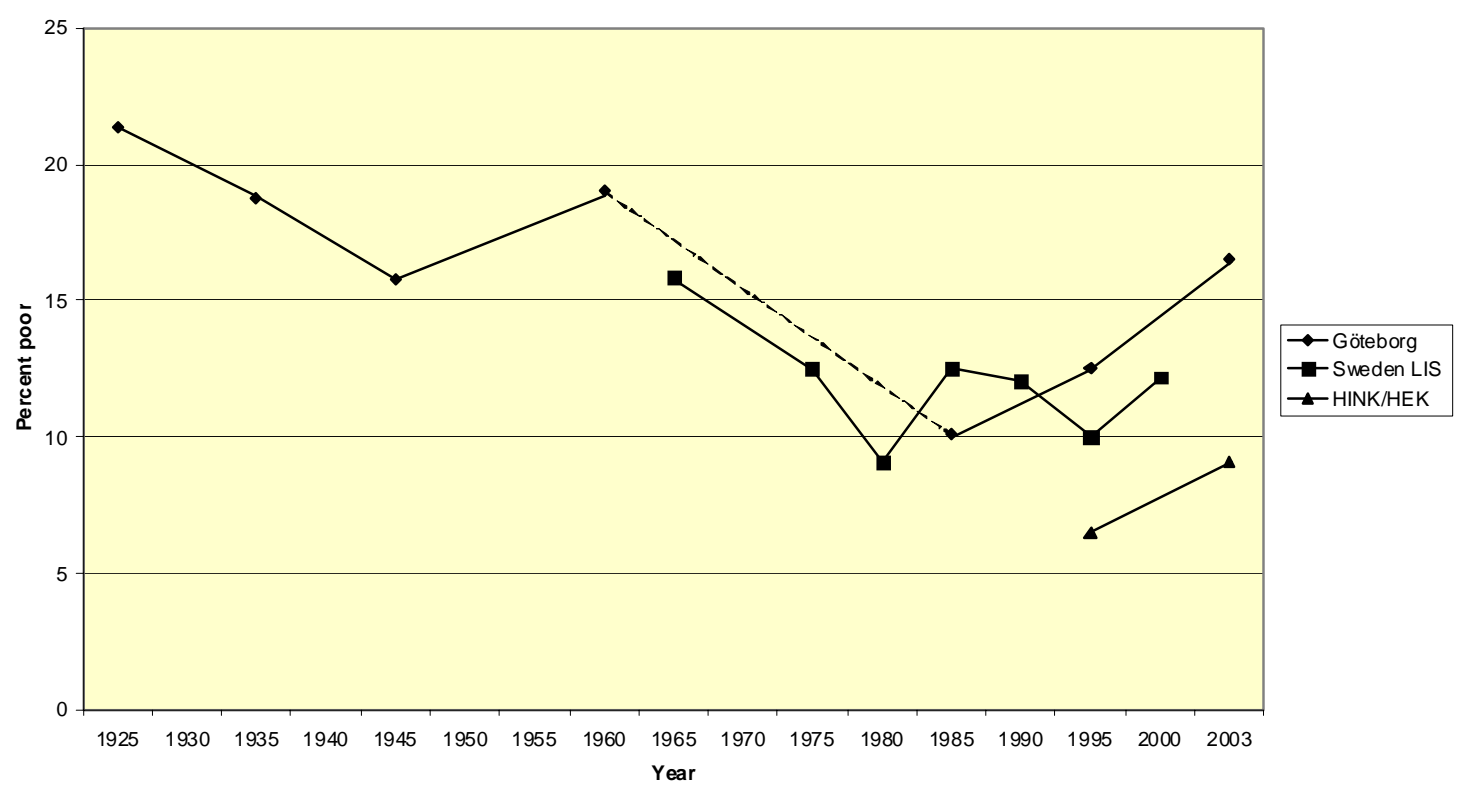

Source: Luxembourg Income Study and authors’ calculations from Göteborg Data, SWIP and HINK/HEK

Figure 2. Share of poverty according to different fixed poverty lines 1925, 1936, 1947, 1958 and 1983. (Poverty line $=60$ percent of disposable income)

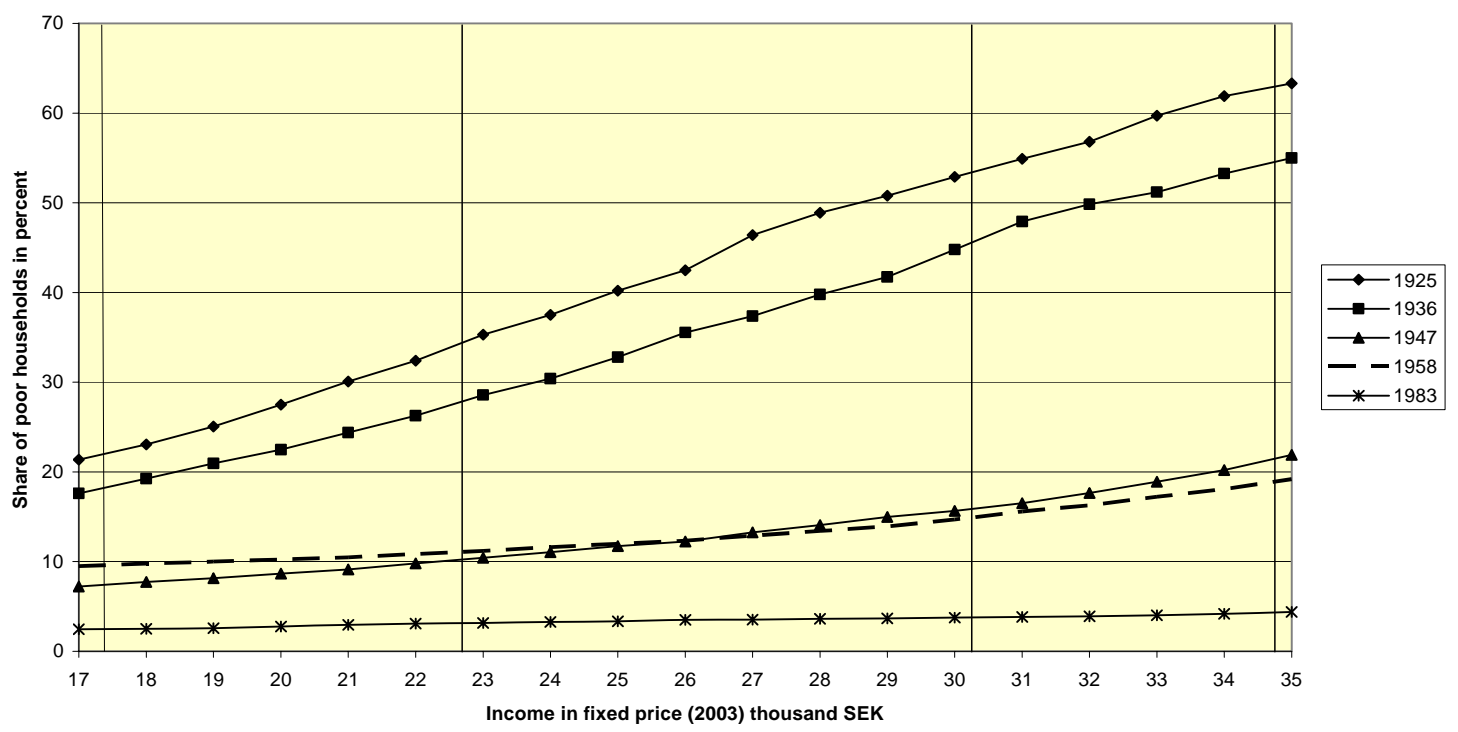

Source: Authors’ calculations from Göteborg Data and Göteborg subsample of SWIP. The vertical lines represent the relative poverty lines for each year starting from the left with 1925, 1936, 1947 an1958. 
Figure 3. Share of poverty according to different fixed poverty lines 1958, 1983, 1994 and 2003. (Poverty line $=60$ percent of disposable income)

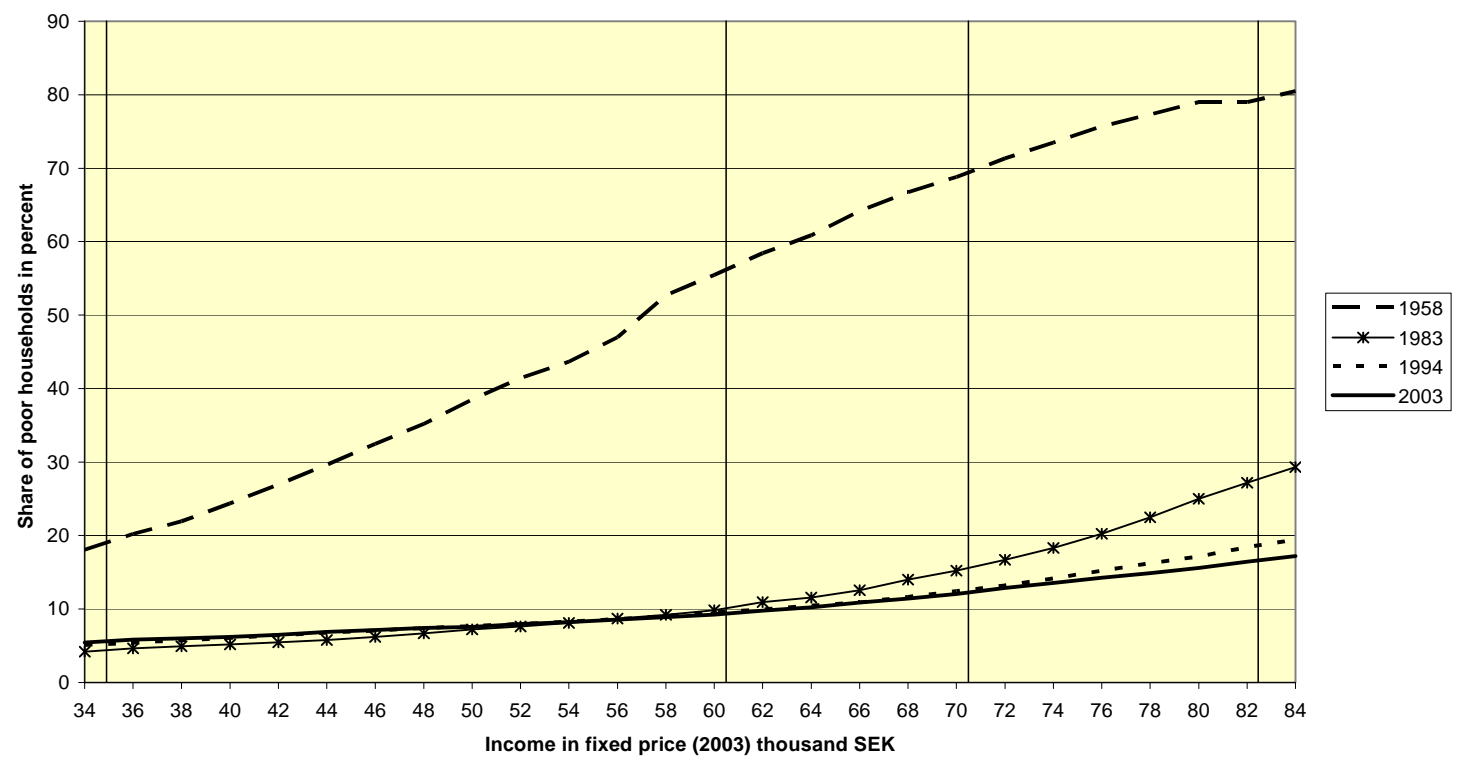

Source: Authors’ calculations from Göteborg data and Göteborg subsample of SWIP. The vertical lines represent the relative poverty lines for each year starting from the left with 1958, 1983, 1994 and 2003.

Figure 4. Age group and relative poverty rates 1925, 1958 and 2003.

(Poverty line 60 percent of median income)

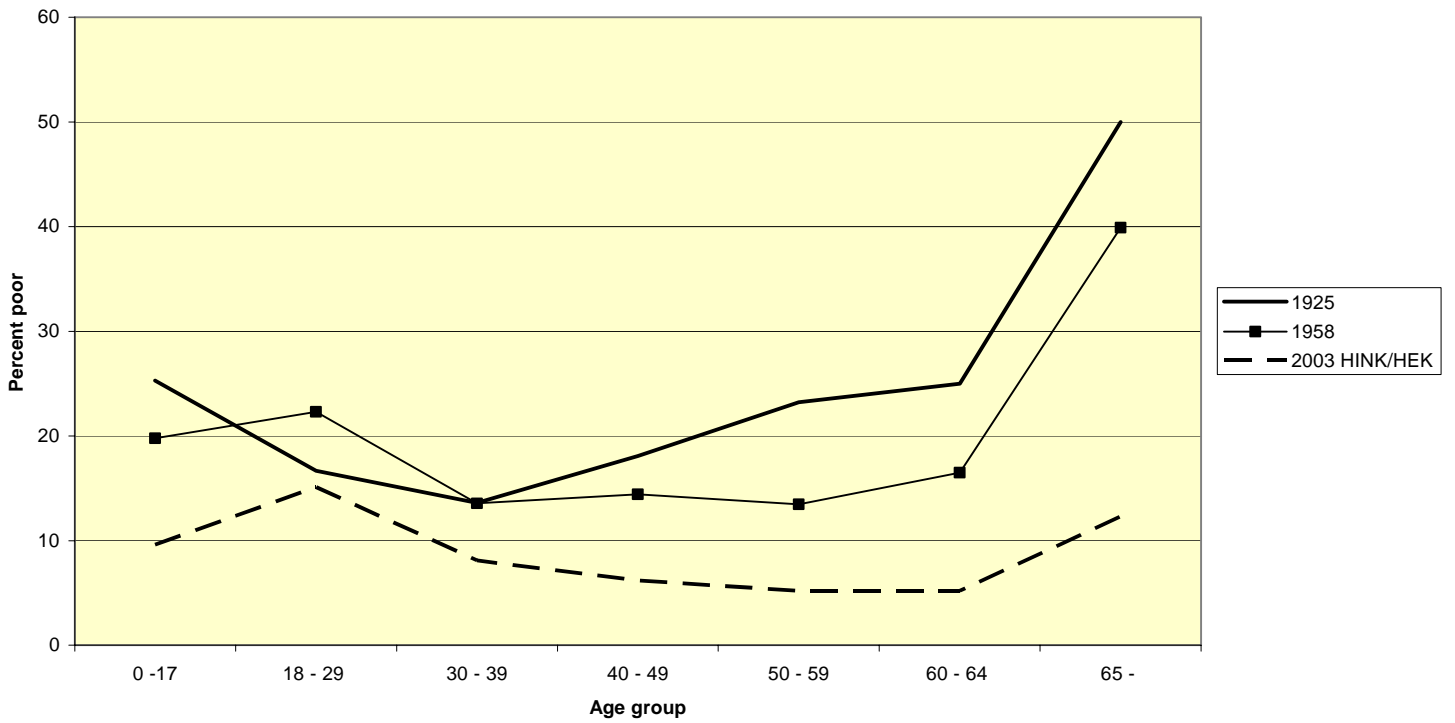

Source: Authors’ calculations from Göteborg Data and HINK/HEK 


\section{Appendix 1}

Table A1 Odds ratio for the years 192519361947 1958. Poverty line (60 percent of median income) for each separate year. For the years 1925x 1936x and 1947x odds ratio is calculated with a poverty line (60 percent of median income) for 1958.

\begin{tabular}{|c|c|c|c|c|c|c|c|}
\hline \multirow{4}{*}{ Intercept } & 1925 & 1936 & 1947 & 1958 & $1925 x$ & $1936 x$ & $1947 x$ \\
\hline & $-1,1563^{* * *}$ & $-0,8362 * * *$ & $-1,3091 * * *$ & $-1,0862^{* * *}$ & $-0,5451 * *$ & 0,1728 & $-0,8308^{* * *}$ \\
\hline & Odds & Odds & Odds & Odds & Odds & Odds & Odds \\
\hline & ratio & ratio & ratio & ratio & ratio & ratio & ratio \\
\hline hhgr1 & 1,302 & $0,594^{* *}$ & 0,850 & 0,703 & $3,641 * * *$ & 1,062 & 0,907 \\
\hline hhgr2 & 1,407 & $3,742^{* *}$ & 1,579 & $4,143^{* * *}$ & $4,649 * * *$ & 2,119 & 1,846 \\
\hline hhgr3 & $0,382^{* * *}$ & 0,751 & $0,612^{*}$ & $1,900 * * *$ & $2,135^{* *}$ & $1,7553^{* *}$ & $0,591 *$ \\
\hline hhgr4 & 1 & 1 & 1 & 1 & 1 & 1 & 1 \\
\hline hhgr5 & $0,424 * * *$ & $0,248^{* * *}$ & $0,235^{* * *}$ & $0,315^{* * *}$ & $0,633^{* *}$ & $0,271 * * *$ & $0,237 * * *$ \\
\hline hhgr6 & $0,657^{*}$ & $0,471 * * *$ & $0,59 * * *$ & $0,603 * * *$ & $2,543 * * *$ & 1,065 & 0,796 \\
\hline hhgr7 & $3,187 * *$ & 1,834 & $3,409 * * *$ & $5,459 * * *$ & $3,127^{*}$ & $3,767 * *$ & $4,291 * * *$ \\
\hline hhgr8 & $2,336 * * *$ & $1,750 * *$ & $1,809^{* *}$ & $1,692 * * *$ & $2,356 * * *$ & 1,388 & $1,600 * *$ \\
\hline scegr1 & 1 & 1 & 1 & 1 & 1 & 1 & 1 \\
\hline scegr2 & $0,560 * * *$ & $0,676^{* *}$ & $0,672 * *$ & $0,765^{* *}$ & $0,617 * * *$ & $0,724 * * *$ & $0,709 * *$ \\
\hline scegr3 & $0,374 * * *$ & $0,391 * * *$ & $0,443 * * *$ & $0,459 * * *$ & $0,162^{* * *}$ & $0,290 * * *$ & $0,398^{* * *}$ \\
\hline scegr4 & $0,129 * * *$ & $0,160^{* * *}$ & $0,329 * *$ & $0,386^{* * *}$ & $0,028^{* * *}$ & $0,125^{* * *}$ & $0,203^{* * *}$ \\
\hline scegr5 & 0,715 & 0,988 & 1,109 & 1,213 & $0,346^{* * *}$ & 0,935 & 1,113 \\
\hline scegr6 & $2,871 * * *$ & $2,736^{* * *}$ & $2,703^{* * *}$ & $1,891 * * *$ & 1,375 & $2,242^{* * *}$ & $2,776^{* * *}$ \\
\hline imgr1 & 1 & 1 & 1 & 1 & 1 & 1 & 1 \\
\hline imgr2 & $1,508^{* *}$ & $1,317^{*}$ & $1,365^{*}$ & $1,464 * * *$ & 1,061 & 1,148 & 0,987 \\
\hline imgr3 & 1,503 & 0,758 & $1,631 * * *$ & 0,963 & 1,073 & $0,526 * * *$ & $1,352^{*}$ \\
\hline imgr4 & $1,516^{*}$ & 1,247 & $1,500^{* *}$ & 1,141 & 0,999 & 1,090 & 1,181 \\
\hline No. of & & & & & & & \\
\hline observations & 1641 & 2197 & 2614 & 3362 & 1641 & 2197 & 2614 \\
\hline Log likelihood & 200.6565 & 264,4523 & 334,3460 & 415,3585 & 371,8937 & 389,0280 & 365,8921 \\
\hline
\end{tabular}

\section{Explanation for abbreviations}

Households groups

hhgr1 Children in family with at least two adults

hhgr2 Children in family with only one adult and adult $(18-64$ years old $)$

living alone together with at least one child.

hhgr3 Adult (18 -29 years old) living alone no children

hhgr4 Adult (30 - 64 years old) living alone no children

hhgr5 Adult (18 - 64 years old) living together with at least one adult, no children.

hhgr6 Adult (18 - 64 years old) living together with at least one adult and at least one child.

hhgr7 Adult (65 years and older) living alone (may have one or more children).

hhgr8 Adult (65 years and older) living together with at least one more adult, (may have one or more children).

\section{Socio economic groups}

scegr1 Unskilled worker

scegr2 Skilled worker

scegr3 White collar

scegr4 Higher employees

scegr5 Self-employed

scegr6 Information missing

\section{Migration groups (Swedish born migration)}

Imgr1 Native born in Göteborg

imgr2 Immigrated to Göteborg $0-4$ years ago

imgr3 Immigrated to Göteborg $5-9$ years ago

imgr4 Immigrated to Göteborg more than 10 years ago 
Table A2. Odds ratio for the years 1994 and 2003. The sample divided into pure Swedish households and pure foreignborn households. For 1994x and $2003 x$ odds ratio is calculated with a poverty line (60 percent of median income) for 1958.

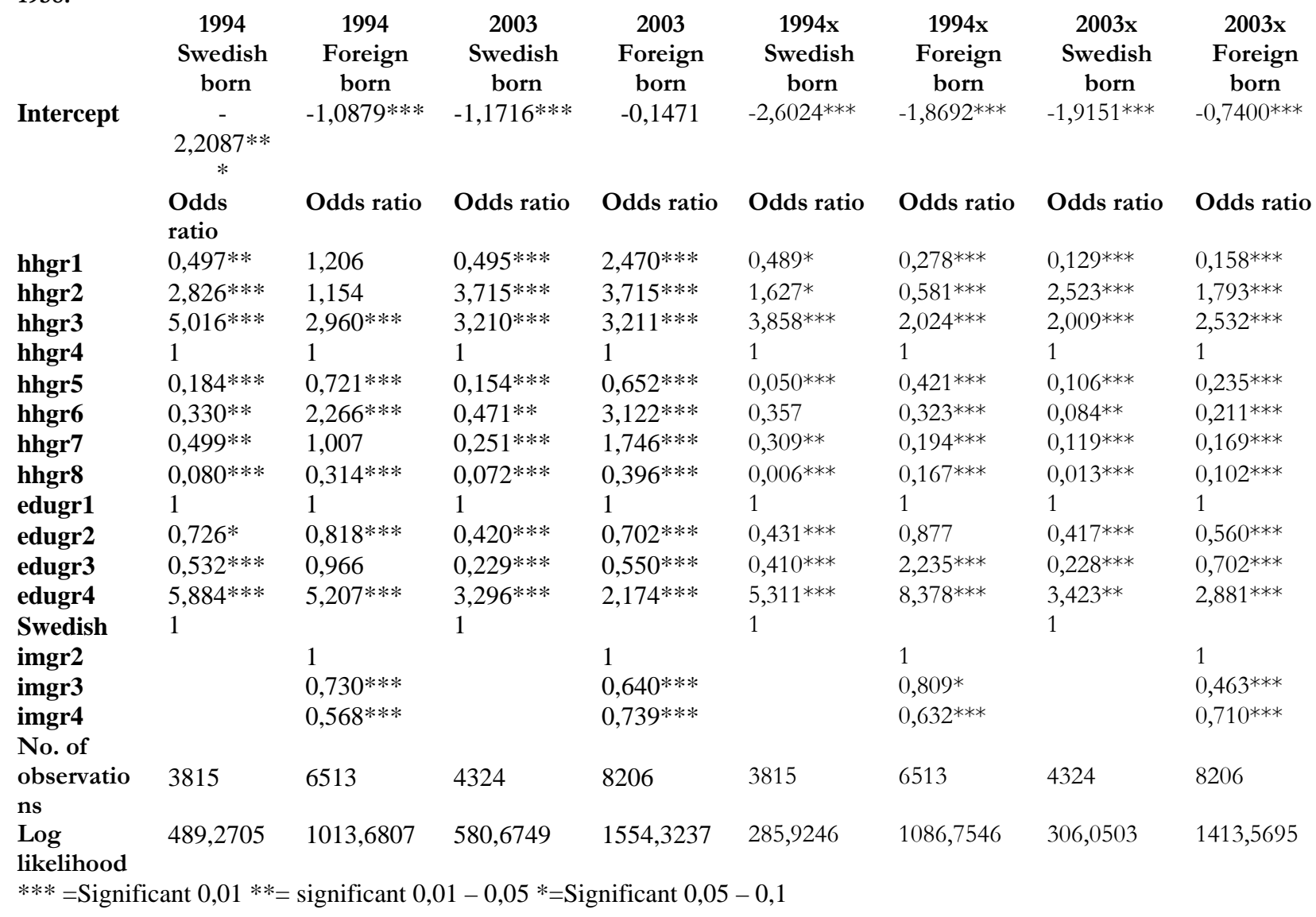

\section{Explanation for abbreviations}

Households groups

hhgr1 Children in family with at least two adults

hhgr2 Children in family with only one adult and adult (18 - 64 years old) living alone together with at least one child.

hhgr3 Adult (18 -29 years old) living alone no children

hhgr4 Adult (30 - 64 years old) living alone no children

hhgr5 Adult (18 - 64 years old) living together with at least one adult, no children.

hhgr6 Adult (18 - 64 years old) living together with at least one adult and at least one child.

hhgr7 Adult (65 years and older) living alone (may have one or more children).

hhgr8 Adult (65 years and older) living together with at least one more adult, (may have one or more children).

Educational groups

edugr1 Low education (elementary education)

Middle education (secondary education and post-secondary education not longer than

edugr2 two years)

edugr3 High education (Post-secondary education longer than two years and university education)

edugr4 Information missing

Immigration groups (foreign born immigration)

Swedish Native, born in Sweden

imgr2 Immigrated to Sweden $0-4$ years ago 
imgr3 Immigrated to Sweden 5 - 9 years ago

imgr4 Immigrated to Sweden more than 10 years ago

\section{Endnotes}


1 Eurostat, (2008) "Income Poverty and Social Exclusion in the EU 25", Statistics in Focus, Organisation of Economic Cooperation and Development (2008), Growing Unequal? Income Distribution and Poverty in OECD Countries, Paris, Luxembourg Income Study (2009) http://www.lisproject.org/keyfigures/

${ }^{2}$ United Nations Development Program (2007) Human Development Report 2007/2008, New York.

${ }^{3}$ The most commonly used measure of the extent of poverty is the poverty rate (the proportion of the population deemed as poor) while the profile of poverty expresses how poverty varies in the population (for example how poverty rates varies by population groups).

${ }^{4}$ On previous assessments of income poverty in Sweden see Gustafsson B., Pedersen, P. J. (2000) Poverty and Low Income in the Nordic Countries. Ashgate Publishing Ltd. and Gustafsson, B. et al (2007) 'Financial Poverty', in International Journal of Social Welfare 16: 67-90. There are also several assessments of poverty in Sweden using the consensus approach, see Halleröd, B. (1995) 'Making Ends Meet - Perceptions of Poverty in Sweden', in Scandinavian Journal of Social Welfare 4 (3): 174- 189 July 1995. Halleröd, B. (2006) "Sour Grapes: Relative Deprivation, Adaptive Preferences and the Measurement of Poverty", in Journal of Social Policy 35: 371-390 (3) as well as Halleröd, B., Larsson, D., Gordon, D.(2006) "Relative Deprivation: a Comparative Analysis of Britain, Finland and Sweden", Journal of European Social Policy 16 (4): 328-345 and Halleröd B. and Larsson D (2008) "Poverty, Welfare Problems and Social Exclusion", International Journal of Social Welfare 17 (1): 15 - 25.

${ }^{5}$ Data on poverty from four years does not allow us to use an econometric / statistical approach, which has been used in recent research on poverty in contemporary societies. For such studies see for example Moller, S., Bradley, D., Huber, E. and Nielsen, F. (2003) ”Determinants of Relative Poverty in Advanced Capitalist Democracies", American Sociological Review, 68, 22-51, Brady, D. (2005) "The Welfare State and Relative Poverty in Rich Western Democracies, 1967-1997", Social Forces, 84, 1329-1364, and Bäckman, O. (2009) "Institutions, Structures and Poverty - A Comparative Study of 16 Countries, 1980-2000”, European Sociological Review, 25 (2), 251-264.

${ }^{6}$ See for example Atkinson, A.B. and Piketty, T. (eds) (2007) “Top Incomes over the $20^{\text {th }}$ Century. A Contrast between Continental European and English-Speaking Countries”, Oxford: Oxford University Press.

${ }^{7}$ Rowntree, S. (1901) "Poverty - Study of Town life." London, McMillan and Co. This book is generally regarded as the first study that used micro data and a poverty line to quantify the extend and profile of poverty. For a biography of Seebohm Rowntree see Briggs, A. (1961) A Study of the Work of Seebohm Rowntree, 1871-1954 : Social thought and social action, London, Longmans.

${ }^{8}$ Rowntree, S. and Lavers, G. R. (1951) "Poverty and the Welfare State.” London, Longmans, Green and Co.

${ }^{9}$ One exception is Piachaud, D. (1988) 'Poverty in Britain 1889 to 1983', in Journal of Social Policy 17 (3): 335 - 349. (1988) who assess how poverty in Britain changed from Rowntree's first work until 1983. For the United States see Ross, C., Danziger, S., Smolensky, E. (1987) 'The Level and Trend of Poverty in the United States, 1939 - 1979 ‘ Demography 24 (4): 587-600 who investigated poverty from 1939 to 1979.

${ }^{10}$ See Citro, C. F. \& Michael, R. T. (eds) (1995) Measuring Poverty. A New Approach. Washington D C, National Academy Press for a detailed discussion as well as for suggestions for improved measurement. 
${ }^{11}$ See for example Atkinson, A. et al (2002) Social Indicators. The EU and Social Inclusion. Oxford: Oxford University Press.

${ }^{12}$ For the concept "Pro-poor growth" see for example Ravalion, M. and Chen, S. (2003) "Measuring Pro-Poor Growth", Economic Letters, 78, 93-9 and Essama-Nssah, B. and Lambert, P. (2009) ”Measuring Pro-Poorness: A Unified Approach”, Review of Income and Wealth, 55 (3), 752-758.

${ }^{13}$ For a now classic theoretical debate on to what extent poverty in rich countries should be conceptualised as being only relative or not, see Sen, A. (1983) "Poor, Relatively Speaking”, Oxford Economic Papers, 35, 153 - 169, Townsend, P. (1985) "A Sociological Approach to the Measurement of Poverty - A Rejoinder to Professor Amartya Sen”, Oxford Economic Papers, 37, 659 - 668 and Sen, A. (1985) "A Sociological Approach to the Measurement of Poverty: A Reply to Professor Peter Townsend, Oxford Economic Papers, 37, 669 - 676.

${ }^{14}$ See for example Krantz, O. (2002)”Svensk ekonomi under 1900-talet: en omväxlande historia.” in Andersson, L. and Krantz, O. (red.) Omvandlingens sekel: perspektiv på ekonomi och samhälle i 1900-talets Sverige. Lund. Studentlitteratur. Schön, L. (2007) En modern svensk ekonomisk historia: tillväxt och omvandling under två sekel. (kap. 4, 5 och 6) Stockholm. SNS förlag. Magnusson, L. (2002) Sveriges ekonomiska historia.(del III och IV) Stockholm Prisma. For the development of the unemployment rates see Axelsson, R. Löfgren, K-G. and Nilsson, L-G. (1983) Den svenska arbetsmarknadspolitiken under 1900-talet. Stockholm, Bokförlaget Prisma. p.119, figur 6.3.

${ }^{15}$ See Olsson K. (1972) Hushållsinkomst, inkomstfördelning och försörjningsbörda. En undersökning av vissa yrkesgrupper i Göteborg 1919 - 1960. Meddelande från Ekonomisk-Historiska institutionen. Göteborgs Universitet., Hibbs, D. (1991) 'Wage Dispersion and Trade Union Action in Sweden' in Person, I. (ed) Generating Equality in the Welfare State. The Swedish Experience", Norwegian University Press, Edin, P-A. and Holmlund, B. (1996) "The Swedish Wage Structure: The Rise and Fall of the Solidary Wage Policy?”, in Freeman, R. and Kats, L. (eds.) Differences and Changes in Wage Structures. Chicago, University of Chicago Press, Gustafsson. B, and Johansson, M. (1998) "Earnings Inequality and the Gender Gap: An Accounting Exercise for Sweden 1975 - 1991”, Labour, 12, 715 - 744., Gustavsson, M. (2006) "The Evolution of the Swedish Wage Structure: New Evidence for 1992 - 2001", Applied Economics, 13, 279-286. Fredriksson. P. and Topel, R. (2006). "Förändrade förutsättningar för svensk lönebildning in Freeman, R. B., Swedenborg, B., Topel, R. (ed) Att reformera välfärdsstaten. Amerikanskt perspektiv på den svenska modellen. NBER Rapporten II, Stockholm, SNS förlag.

${ }^{16}$ Hort, S. E. O. (1993) Social policy and welfare state in Sweden. Lund studies of social welfare 3. Lund, Arkiv, Lundberg, U. and Åmark, K. (2005) Hundra år av välfärdspolitik. Välfärdsstatens framväxt i Norge och Sverige. Umeå, Boréa. and Edebalk, P. G. (1996) Välfärdsstaten träder fram. Svensk socialförsäkring 1884 - 1955. Lund studies of social welfare XII, Ystad, Arkiv förlag.

${ }^{17}$ For a description of the development of unemployment insurance see Edling, N. (2006) "Limited Universalism: Unemployment insurance in Northern Europe 1900 - 2000.” in Christiansen, N. F., Petersen, K., Edling, N. and Haave, P. (ed.) The Nordic Model of Welfare. A Historical Reappraisal. Museum Tusculanum Press, University of Copenhagen.

${ }^{18}$ The proportions are from the Censuses see Stanfors, M. (2003) Education, Labour Force Participation and Changing Fertility Patterns. A Study of Women and Socioeconomic Change in Twentieth Century Sweden. Lund Studies in Economic History 22. On the gender wage gap see for example Svensson, L. (1995) Closing the Gender Gap. Determinants of the Change in the Female-toMale Blue-collar Wage Ratio in Swedish Manufacturing 1913-1990. Lund: Skrifter utgivna av Ekonomisk-historiska föreningen i Lund Vol. LXXI. and Johansson. M., Katz, K. and Nyman, H. (2005) 'Wage Differentials and Gender Discrimination - Changes in Sweden 1981-98” Acta Sociologica 48 (4): 341 - 364. Axelsson, C. (1992) Hemmanfrun som försvann. Övergången till 
lönearbete bland gifta kvinnor i Sverige 1968 - 1981, Stockholm: Stockholms Universitet, Institutet för social forskning avhandlingsserie 21. p 108 reports statistics on married women's economic dependence for selected years.

19 Åmark, K. (2006) “Women’s Labour Force Participation in the Nordic Countries During the Twentieth Century.” in Christiansen, N. F., Petersen, K., Edling, N. and Haave, P. ed. (2006) a.a. Åmark, K. (2002) "Familj, försörjning och livslopp under 1900-talet.” in Bergman, H., Johansson, P. (red.) Familjeangelägenheter. Modern historisk forskning om välfärdsstat, genus och politik. Stockholm/Stehag, Brutus Östlings bokförlag Symposion. Stanfors M. (2007) Mellan arbete och familj. Ett dilemma för kvinnor i 1900-talets Sverige. Stockholm. SNS förlag.

${ }^{20}$ On research on the transition from education to working life see for example Ryan, P. (2001)”The School to Work Transition: A Cross-National Perspective”, Journal of Economic Literature, 39, p 34 - 92. For studies on financial transfers across households in Sweden see Fritzell, J. Lennartsson, C. (2005) "Financial Transfers between Generations in Sweden” Ageing and Society, 25, p 1 - 18 as well as Björnberg, U. and Latta, M. (2007) "The Roles of the Family and the Welfare State. The Relationship between Public and Private Financial Support in Sweden.” in Current Sociology 55 (3): p $415-445$.

${ }^{21}$ See for example Gustafsson, B. and Zheng, J. (2006)”Earnings of Immigrants in Sweden from 1978 to 1999”, International Migration, 44, p 79 - 117 and references quoted there and Carlsson, M. and Rooth, D. (2007) "Evidence of Ethnic Discrimination in the Swedish Labour Market Using Experimental Data”, Labour Economics, 14, p 716 - 729. On poverty among immigrants see Blume, K., Gustafsson, B., Pedersen, P.J. and Verner, M. (2007) “At the Lower End of the Table: Determinants of poverty among Immigrants to Denmark and Sweden, Journal of Ethnic and Migration Studies, 33, p 373 - 396.

${ }^{22}$ The book by Olsson, K. (1996) Göteborgs historia: Näringsliv och samhällsutveckling 3. Från industristad till tjänstestad 1920 - 1995. Stockholm. Nerenius \& Santérus förlag, provides a thorough and highly readable description of the economic and social development of the city for the same period as here studied.

23 For a more thorough description of the database see Gustafsson, B. and Johansson, M. (2003) 'Steps toward equality. How and why Income inequality in urban Sweden changed during the period 1925 - 1958.' in European Review of Economic History 7, 191 - 211 who also report Gini coefficients computed from the data. The database is also used by Gustafsson, B. and Jansson, B. (2008) "Top Incomes in Sweden over Three-Quarters of a Century: A Micro data Approach”, Cambridge Journal of Economics, 32, (6), p 963 - 976 to investigate the evolution of top incomes.

${ }^{24}$ When deriving results for the entire population of Göteborg we correct for the different probabilities of being included by taking a 10-percent sample of the foreign-born sample. We faced the problem in the 1983 data that no children born 1979 to 1983 and their parents were found. Thus, our results from 1983 should be considered as more preliminary than the results for other years.

${ }^{25}$ HINK/HEK excludes persons living in institutions, those who have immigrated or emigrated during the year and some others, a procedure that probably leads to lower poverty counts. Around 30 percent of respondents to HINK/HEK do not answer due do various reasons. In order to correct for this, Statistics Sweden has developed sample weights which we also apply in our tabulations. In contrast, by being register based, SWIP does not face problems of non-response.

${ }^{26}$ Inspecting tables show that estimates of size of fraction of persons living in the Göteborg region that fall under a poverty line set to 60 percent of contemporary median income in Sweden are rather close to estimates for Sweden as a whole. In 2003, 8.6 percent of persons living in the Göteborg region fell 
under the 60-percent line while the poverty rate for the country as a whole was 9.1 percent. The 1995 rates were 5.9 percent (Göteborg) and 6.5 percent (Sweden as a whole).

${ }^{27}$ See for example Atkinson, A. et al, (2002) p. 98-99

${ }^{28}$ http://www.lisproject.org/

${ }^{29}$ Given than the 1983 estimate is based on SWIP, a source for the same year producing higher poverty rates than HINK/HEK, the recorded drop in poverty rate is most probably an underestimate rather than an overestimate.

${ }^{30}$ Following many before us, we update the poverty line by the Consumer Price Index, which is available for the entire period and which is computed for average consumption. It can be debated, however, how well this represents the consumer prices met by people with low incomes.

${ }^{31}$ We here use poverty rates calculated from HINK/HEK 2003. Poverty rates for the same year calculated from the SWIP subsample is considerably higher due to, for example, the definition of the household. In this section we find more confidence in poverty rates calculated from HINK/HEK.

${ }^{32}$ See for example Wong, Y.L.I., Garfinkel, I., and McLanahan, S. (1993) "Single-Mother Families in 8 Countries - Economic-Status and Social Policy.” Social Service Review 67 (2): p 177-197.

${ }^{33}$ In this data is occupations classified in a scheme with different levels, where the lowest has around 1000 categories. We merge the 13 categories that were used in the Census of 1985 into the categories "Unskilled worker", "Skilled worker”, "White collar", "Higher employees", "Self-employed" and "Information missing".

${ }^{34}$ Please note that in the specification we also include a dummy variable indicating lack of information on socioeconomic status / education of the household head. In all cases such coefficients indicate considerably higher poverty risks than the status low-skilled worker /low-educated.

${ }^{35}$ See note 24 for the motivation for not presenting predictions for 1983.

${ }^{36}$ Note that the development of poverty in Göteborg as a whole is also based on changed population composition. For example, the proportion of low-skilled families decreased during most of the period studied.

${ }^{37}$ Rowntree, S. (1941) "Poverty and Progress. A Second Social survey of York." London ,Longmans, Green and Co. 